\title{
Women in Domestic Violence in Nigeria: Gender Perspectives
}

\author{
Anthonia O. Uzuegbunam \\ Public Administration and Local Government University of Nigeria, Nsukka, Nigeria \\ Email: toniauzuegbunam@yahoo.com
}

Received September $5^{\text {th }}, 2012$; revised October $7^{\text {th }}, 2012$; accepted October $22^{\text {nd }}, 2012$

\begin{abstract}
Theoretically, violence is a human rights issue, and human rights are fundamental to values of dignity, equality, non-discrimination and non-interference, and these cut across gender, social, cultural, political, class, religious and geographical issues. Human beings, properties and resources are in millions daily destroyed. Children are abused. Women remain injured and humiliated, so much so that men's status seemed to be changing. Hence, this study embarked on examining Women in Domestic Violence in Nigeria using gender perspectives. Among the findings is that in many parts of Nigeria, women and girls are subjected to physical, sexual and psychological abuse that cuts across lines of income, class, religion and culture. Recommendations made include the following: adoption of concerted or integrated approach to decision making and implementation.
\end{abstract}

Keywords: Women; Domestic Violence; Gender; Perspective

\section{Introduction}

A manifestation of historically unequal power relations between genders is a reflection of domestic violence against women. This in turn led to domination, discrimination and abuse against women. Such an existence in society contributed to slow pace of women advancement or development. Thus, violence against women is as a result of power imbalances, cultural beliefs and social structures that perpetuate these ills. Oftentimes women and female children are synonymous with the kitchen. Some of these women are voiceless no matter the treatment meted to them. In effect domestic violence in Nigerian society is applied as a mechanism for controlling the ambitious tendencies of some women. As a consequence, womenfolk unfortunately exploit this situation in society by constituting themselves ardent perpetrators of violence or abuse on women and children.

Indeed the roles played by such perpetrators like the males, close relations, partners and the society itself have been expressed and even documented but that played by the women themselves is extant in literature and as such is played down in recognition. Against this background this paper attempted to analyse violence and abuse against women and children as perpetrated by women themselves and proffer useful strategies towards the reduction of violence and abuse against women in society. Specifically, the paper raised and attempted to answer the following research questions:

- What areas can be identified as situations of domestic violence on women by women?

- Who are the women that are most frequently at risk of women violence by women?

- In what forms can women violence by women be identified?

- How do male and female genders perceive women violence by women in society?

- What strategies could be adopted towards the reduction of women violence in Nigerian society?

However, the above research questions were analyzed using Tables 1-6. Table 1 showed the background information of the respondents like age, sex, religion, educational qualification etc. Table 2 indicated the women most frequently at risk of women violence by their follow women. Table 3 indicated the forms of violence against women by fellow women in percentages. Table 4 showed the effects of women violence by fellow women. Table 5 indicated the best considered strategy "Self Searching Management" (SSM) by sex. And Table 6 summarized table of regression analysis showing SSM as the dependent variable.

\section{Conceptual Framework}

Violence carries with it varied definitions depending on the definer and the situation in which it is defined. Violence connotes rough treatment, use of bodily force on others, especially unlawfully, to hurt or harm. It is also regarded as an act of human inflictions, deprivations and discrimination resulting in or likely to result in unlawful physical, sexual and psychological harm, suffering or deprivation (UN, 1993). Furthermore, violence is perceived as the use of physical force, accompanied by fury, violence or outrage, (Arinze, 2008). It is also described as the utilization of physical force that induces damage or injury, intense natural force or energy, an abusive use of force, passion, fury, disturbance and desecration, (US Office: 2004; UN, 2008). As a corollary, domestic violence is perceived as violence among members of a family, same household, clan etc. Thus, operationally, domestic violence connotes violence perpetrated and occasioned at home by known and identified individuals or groups. Domestic violence includes any aggressive behaviour or maltreatment among intimate partners which occur in privacy of a home, family or clan. These include all hostile acts committed by any family members against another, spouse, parents, child, siblings, grandparents, in-laws etc, irrespective of sex, status, race, age, religion or emotional state. It can be in 


\section{A. O. UZUEGBUNAM}

form of aggressive behaviours by which the victims are physically or emotionally disturbed or harmed. Thus, any threat/or indecent assault, personal or economic intimidation, undue curtailment of freedom, any expression that reduces a person's dignity, any physical assaults, blows, beating, strangulations that are complete or incomplete, jabs with sharp or blunt objects, slaps, kicks, sexual abuse of any kind, inordinate sexual demand and or refusal, etc., constitute manifestations of violence within the home, household or family, clan etc., (Uzuegbunam, 2009).

Violence against women can be defined in various ways. For instance, violence against women is perceived as gendered violence directed at women for the very fact of being women, (Spain office, OVW, 2004). However, UN, (1993) described violence against women as any act of gender-based violence,

that results in, or is likely to result in physical, sexual or psychological harm, or suffering to women, including threats of such acts, coercion or arbitrary deprivation of liberty, occurring in public or private life.

Hence any violence directed to the female gender either by male gender or by the females themselves is regarded as violence against women. However, the more horrifying aspect of violence is that perpetrated by women themselves on women. Here lies the thrust of this paper as a point of departure from many available documentation of domestic violence in the society.

The concept of "women" is derived from our perception of the sex in animals or plants that produce or are capable of producing eggs and bearing young ones. It also relates to any reproductive structure that contains elements to be fertilized by male elements. Hence the word women incorporates adult females, girls and babies since they all have attributes of feminine gender, (Arinze, 2008). In Nigeria, the concept and role of women are biologically, culturally, historically, institutionally and situationally defined. Biologically, women in Nigeria are understood as the concept explained above i.e. feminine gender. Culturally, women are perceived as profane creatures that deserve no respect and as such should be treated as sub-ordinates to men. They should not be heard in any discussions or decision-making. Their place is always in the kitchen. They cannot think for themselves and their thoughts are considered worthless. They should not eat certain foods or meat. They should not have access to any inheritance including land. The married ones are regarded as men's property that could be beaten up or thrown away at the least point of provocation. Any wrong doing in society is attributed to the women especially bad behaviours of children in society. Historically, women were understood as inconsequential creatures who could not contribute meaningfully to societal development. But today some women in top national, state and local government positions have proved that women possess the potentials for societal development. So, women are today understood as useful partners in societal development. Institutionally, women in Nigeria are seen as an institution in themselves. They are regarded as the second class citizens of the society doing things in groups and in their own way. They should not be regarded as having the same nature with male folk and as such are not equal in the eyes of the society. Situationally, women are perceived as catalysts in certain situations and as agents of doom in other situations. For instance, in conflict resolutions and management the women are seen to be the force that could calm down the situation after all efforts of the males have failed. But at the time of benefits and dividends sharing, women are conceived to be sub-ordinate and inconsequential group in society. Against these various perceptions of the concept of women in Nigeria society, the various treatment of women in society were derived. Hence, the idea of discrimination, degradation, disrespect, deprivation of rights and priviledges etc. emerged.

The idea of gender is simply derived from the state of masculine and feminine. It is a division into male and female groups in society. It has to deal with sex structure in human being making them behave the way they do. Thus it refers to men and women in society which in turn affect their perceptions of domestic violence and women in Nigerian society.

Philosophically, women in domestic violence in Nigeria should be understood from the African world View or philosophy. This world view is based on the theistic charter that explains the interaction or relationship of human beings in the society including marriages from the system of values existing in that society, (Dukor, 2010). Thus, for Africans, every sex group, Dukor continued, is organized on the existence of certain division of labour, and distribution patterns of privileges and duties. These subsequently require skills, habits and legal standards for satisfying needs, Hence, in pre-colonial Africa, Nigeria inclusive, the epistemological foundation specified that there was no intention for inequality, injustice and lack of freedom.

Thus, this charter, Dukor appropriately referred to as Africa theistic existentialism and it should be respected so as to accord the mother earth her due deference.

However, people including women, accepted this basic ontological thesis, until some exploitation and manipulations of existing norms and values of epistemological foundation of Africa gender set in. As a result of modern education, complexities of life and obvious impacts of development and globalization, the world, including women perceive some of the positions of women as violence against them.

Again, Dukor, (2010: p. 65) diagrammatically explained the different faces of gender consciousness. He traced the gender class struggle from gender classless ontological regime, which moved into gender community of balanced psychic and material order and arrived at the struggle. What is being explained here philosophically is that there are three broad stages of gender stress ontology. The first stage " $A$ " shows no gender differentiation which he called gender classless being People innocently understood themselves as one specie of humanly. Then, for purposes of interaction and mutual healthy procreation, the next stage "B" referred to as Gender community set in. Finally, through the colonial experiences, the regime of acute differentiation of male and female with modern ontology disregarded the African ontology which resulted in gender class struggle (See Figure 1), it is the present situation that prompted feminist studies.

Consequently, Dukor, proposed that what the African philosophy is prescribing to any gender discourse is to base the work on classless social order that is free from gender class struggle. The studies should be based on vital opportunities that facilitate the realization of women's aspiration and goals in life. Dukor's views point on this paper on Women in Domestic Violence is an exposition that women's violence problem should be tackled from women's self-solution since most of the sufferings are women self-affliction or implementation of societal prescriptions. 
A

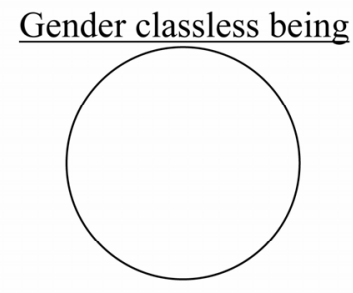

$\mathrm{B}$
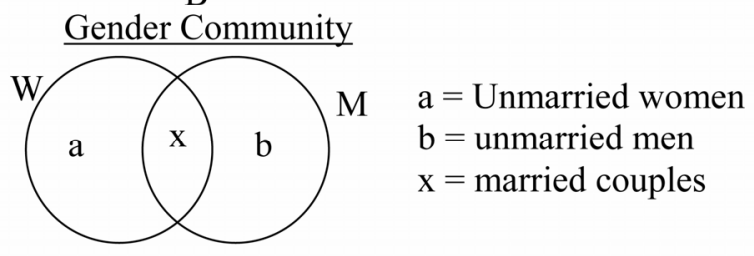

$\mathrm{C}$

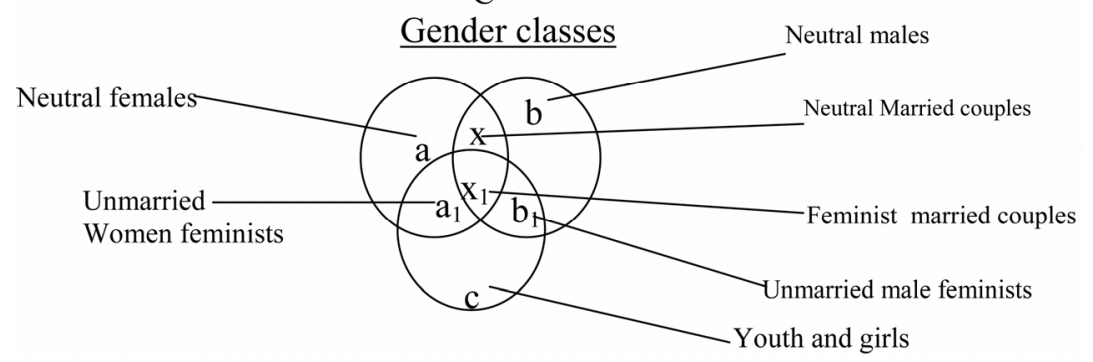

Figure 1.

Gender stress ontology venn diagram. Source: Dukor, M. (2010). Gender discourse in Africa epistemology.

\section{Rationale for Observation of Fundamental Human Rights among Women in Nigeria}

The rationale behind the objective of this paper stems from the observation that despite the constitutional provision of fundamental rights of the individuals irrespective of gender, women are still everywhere in chains. For instance, the Federal Republic of Nigeria 1999 Constitution, in its chapter IV captioned "Fundamental Rights" provides for equality under the law. It guarantees the right to life and protection from inhuman and degrading treatments. In addition to the rights provided by the constitution, other provisions in our criminal and penal codes, which identify certain actions as crimes were also provided. Examples include sexual and non-sexual assaults. There are of course standard setting instruments below which a nation cannot fall without being barbaric. These include Universal Declaration of Human Right (UDHR), and Elimination of All Forms of Discrimination Against Women (CEDAW). To these instruments Nigeria signed and ratified without reservation. Even the National Assembly has been trying to make it a domestic law, including the hindrance created by section 12 of the 1999 constitution. This section 12 provides for Declaration on Elimination of All Forms of violence against women. The African character on Human and Peoples Rights, which has already been domesticated, also guarantees these rights aforementioned. Furthermore, the Supreme Court in Abacha vs. Fawehinmi stated that the African Charter like chapter IV of the 1979 and 1999 constitution of Nigeria grants rights and obliga- tions to all African Union (AU) member states citizens.

These rights and obligations granted by both national and international treaties and conventions ought to be enforced. Yet, various crimes of domestic violence against women are still perpetrated in Nigerian society with equanimity. It is high time, women and the law rose up to this challenge. Thus, the present research sought to determine whether various forms of women violence perpetrated by women is a contributing factor for the persistence of violence against women in Nigerian society and proffered the best considered strategy for reduction of the scourge. It was then hypothesized that there would be significant prevalence of various forms of violence against women perpetrated by women and that there would be no significant gender difference in the prevalence and best considered strategy for its reduction.

\section{Methods}

\section{Sample}

A sample of 900 participants from the total Nigeria population of 140.3 million people (2006 population census) was initially selected. Nigeria has six (6) geo-political zones. Stratified random sampling was applied to select the respondents from each of the six zones. Out of the 900 sampled, 140 (15.56\%) did not return the questionnaire, $20(2.22 \%)$ returned the questionnaire but uncompleted, while responses of 40 participants were not analyzed as a result of omission of items. Thus, the 


\section{A. O. UZUEGBUNAM}

analysis was based on 700 participants. The participants consisting of 360 males and 340 females were of the age range within 15 years - 55 and above with mean age of 22.3 years and standard deviation of 1.18. Majority of respondents $616(88.0 \%)$ were married, $81(11.5 \%)$ were single and $3(0.4 \%)$ were divorced. Christians among the participants were 660 (94.3\%) while Muslims and others 40 (5.7\%). Many of the respondents were literate, the highest number coming from WASC/GCE $339(48.4 \%)$ and the least number received were from the Ph.D/ Equivalent $3(0.4 \%)$. Duration of the study was 18 months.

\section{Instrument}

The instrument used for this study was a set of questionnaire consisting of 14 statements of violence against women as perpetrated by women in society. In its likert-type questionnaire, some of the statements were positively stated while others were negatively stated. The first part of the questionnaire contains demographic data on the respondents. The second part were substantial to the study meant to assess the respondents' perceptions about violence committed against women by women. Again two sets of focused group discussion based on the statements of the questionnaire were organized. One session was for males and another for female respondents. Data from secondary source like other people's work, the library and the dailies also supported the data collection.

\section{Procedure/Measures}

Violence against women by women in forms, areas, effects and strategy for reducing women's violence in society were measured based on a ranked 14-variables questions scale. The ranking was based on responses to the variables as: strongly agree -5 points; agree -4 points; disagree -3 points; strongly disagree -2 points and undecided -1 point.

The questionnaire was administered individually using 6 field research assistants. One research assistants for each zone using 150 respondents for each zone, was adopted. Using this scale, the respondents were scored. If for instance, the perpetrators of women violence using the co-wives of same clan were scored, the highest mark obtained was 269 for strongly agree while the lowest mark was 17 for strongly disagree $(\mathrm{M}=$ $1.8, \mathrm{SD}=1.1$ ). Based on this scoring, the data collected were analyzed. $\mathrm{X}^{2}$ test of association and regression co-efficient were also adopted to ascertain significance of the relationship of gender perception and the best considered strategy for reduction of women violence by fellow women.

\section{Results}

Analysis of findings derived from research questions.

Table 1 showed the background information of the respondents like age, sex, religion, educational qualification etc. However, the findings from the study show that participants willingly responded to all the statements on violence against women by fellow women from different sexes, ages, religion, educational qualification, marital status and cultural or geopolitical zones of Nigeria. This explains that the respondents have either witnessed the violence or have been victims themselves. Thus, for question on various perpetrators and areas of perpetration, the respondents gave such perpetrators as "daughters of same family or clan (Umuada)" with agree - 4 points scoring the highest $298(42.6 \%)$ and strongly disagree scoring
Table 1.

Percentage distribution of respondents by background information.

\begin{tabular}{|c|c|c|}
\hline Variable & Frequency & Percentage $(\mathrm{N}=700)$ \\
\hline \multicolumn{3}{|l|}{ Sex } \\
\hline Male & 360 & 51.4 \\
\hline Female & 340 & 48.6 \\
\hline \multicolumn{3}{|l|}{ Age: } \\
\hline $15-19$ & 166 & 23.7 \\
\hline $20-24$ & 291 & 41.6 \\
\hline $25-29$ & 171 & 24.4 \\
\hline $30-34$ & 38 & 5.4 \\
\hline $35-39$ & 9 & 1.3 \\
\hline 40 and above & 15 & 2.1 \\
\hline \multicolumn{3}{|l|}{ Marital Status: } \\
\hline Married & 616 & 88.1 \\
\hline Unmarried & 84 & 11.9 \\
\hline \multicolumn{3}{|l|}{ Geo-Political Zone: } \\
\hline North-North & 82 & 11.71 \\
\hline North-Central & 97 & 13.85 \\
\hline North-West & 116 & 16.57 \\
\hline South-South & 120 & 17.14 \\
\hline South-West & 140 & 20.00 \\
\hline South-East & 145 & 20.713 \\
\hline \multicolumn{3}{|l|}{ Religion: } \\
\hline Christianity & 426 & 60.86 \\
\hline Islamism & 224 & 32.00 \\
\hline Others & 50 & 7.14 \\
\hline \multicolumn{3}{|c|}{ Highest Educational Qualification: } \\
\hline Primary School & 18 & 2.6 \\
\hline WASC/GCE & 339 & 48.4 \\
\hline National & 103 & 14.0 \\
\hline Diploma/HND & 217 & 31.0 \\
\hline \multicolumn{3}{|l|}{ First Degree } \\
\hline Masters Degree and above & 40 & 5.7 \\
\hline
\end{tabular}

Source: prepared by the researcher from field work 2010 .

the least 25 (3.6\%). For perpetrators as "women co- wives of the same family or clan" "agree" -4 points scale, scored the highest 297 (42.4\%) with "strongly disagree" scoring 17 (2.4\%). For perpetrators as women in politics, "agree" -4 points scale scored the highest 221 (31.6\%) with "strongly disagree" scoring the least $63(9.0 \%)$. Perpetrators as women in same zones of religion activities "agree"-4 points scale scored $176(25.0 \%)$ as the highest, while "undecided" scored the least of $102(14.6 \%)$. Perpetrators as "women in same occupation, "agree" -4 points 


\section{A. O. UZUEGBUNAM}

scale scored $218(31.1 \%)$ as the highest while strongly disagree -2 points scored the least mark of $42(6.0 \%)$.

Women most frequently at risk of women violence by fellow women, forms of violence or abuse on women by fellow women, perceptions of respondents about the women violence by fellow women and respondents perceptions on the best considered strategy, were also responded to by the participants. These were distributed in the tables below:

Table 2 indicated the women most frequently at risk of women violence by their follow women. And from the table, it shows that the childless women $340(48.6 \%)$ scored the highest measure of credibility, followed by the widows 318 (45.4\%), the women poor $287(41.0 \%)$, the illiterate women 283 , $(40.4 \%)$, the women employees, $254,(36.3 \%)$, the women political aspirants, $218(18.9 \%)$ and others $12,(1.7 \%)$ in that order of ranking.

Table 3 indicated the forms of violence against women by fellow women in percentages. By ranking of the scores made, widowhood rituals scored the highest $310(44.3 \%)$ then followed by chasing her out of her husband's house 249 , $(35.6 \%)$, deliberately denying her rights and dues, 230, $(32.9 \%)$, humiliating the victim $182,(260.0 \%)$, isolating the victim from her family and friends, $176,(25.1 \%)$, making the victim feel embarrassed 175, (25.0\%) women and children trafficking $147(21.0 \%)$, controlling what the victim can do or cannot do 138, (19.7) and withholding information, 111 (15.9\%) in that order.

Table 4 showed the effects of women violence by fellow women. Therefore, since the mean is above 2.5 , it therefore indicates that the difference between satisfactory and dissatisfactory effects of women violence by fellow women is significant as tested through the use of mean, standard deviation and $\mathrm{X}^{2}$ chi square test of association.

Table 5 indicated the best considered strategy "Self Searching Management" (SSM) by sex.

\section{Test of Hypothesis}

Ho: The hypothesis states that there is no significant difference between gender and perceptions of SSM as the best considered strategy for reduction of women violence.

Where Equation:

$$
\mathrm{y}=\mathrm{mx}+\mathrm{b}=0.155(\mathrm{x})+0.787
$$

are the regression coefficients; 0.155 is the value of slope of the line; 0.787 is the interception on the y axis; $\alpha$ means the level of significance, the probability of rejecting the Ho when it is not true. Significance is the calculated value of level of variation and is compared to the level $\alpha$; $\alpha$ means alpha value which is always 0.05 .

Table 5 showed the perceptions of the respondents to SSM by sex. From there the test regression coefficient was employed in testing the hypothesis which states that there is no significant difference in the opinions of gender on the best considered strategy SSM. The first part of the table indicates the needed statistics for discussing the rate of variation in SSM evaluation, which can be explained by gender or sex effects. The value of $\mathrm{R}^{2}$ shows the combined effects of both sexes. This $\mathrm{R}^{2}$ value of 0.00018 means that less than 1 percent variation in SSM analysis was explained by the combined effects of both sexes.

The $B$ value of $0.787+0.155$ in the table, measured the regression coefficients indicating the effects of both sexes. Thus,
Table 2.

Participants responses on the women most frequently at risk of women violence by their fellow women.

\begin{tabular}{cccc}
\hline Rank & Women's Group & Frequency & Percentage \\
\hline 2 & The widows & 318 & 45.4 \\
6 & The women political aspirant & 218 & 31.1 \\
3 & The women poor & 287 & 41.0 \\
5 & The women employees & 254 & 36.3 \\
7 & The women great achievers & 132 & 18.9 \\
1 & The childless women & 340 & 48.6 \\
4 & The illiterate women & 283 & 40.4 \\
8 & Others, specify & 12 & 1.7 \\
\hline
\end{tabular}

Source: prepared by the researcher from fieldwork 2010 .

Table 3.

Participants' responses by forms of violence on women by fellow women in percentages.

\begin{tabular}{|c|c|c|c|}
\hline Rank & Forms of Violence & Frequency & Percentage \\
\hline \multirow[t]{2}{*}{1} & $\begin{array}{l}\text { A: Widowhood rituals e.g. drinking } \\
\text { of water used in bathing the dead } \\
\text { husband. }\end{array}$ & 310 & 44.3 \\
\hline & $\begin{array}{l}\text { B: Emotional and psychological } \\
\text { violence. }\end{array}$ & & \\
\hline 7 & - Women and child trafficking & 147 & 21.0 \\
\hline 4 & $\begin{array}{l}\text { - Humiliating the victim publicly or } \\
\text { privately }\end{array}$ & 182 & 26.0 \\
\hline 8 & $\begin{array}{l}\text { - Controlling what the victim can or } \\
\text { cannot do }\end{array}$ & 138 & 19.7 \\
\hline 9 & $\begin{array}{l}\text { - Withholding information from the } \\
\text { victim }\end{array}$ & 111 & 15.9 \\
\hline 2 & $\begin{array}{l}\text { - Chasing her out of her husband's } \\
\text { house }\end{array}$ & 249 & 35.6 \\
\hline 6 & $\begin{array}{l}\text { - Making the victim feel embarrassed } \\
\text { and rejected }\end{array}$ & 175 & 25.0 \\
\hline 5 & $\begin{array}{l}\text { - Isolating the victim from family and } \\
\text { friends }\end{array}$ & 176 & 25.1 \\
\hline 3 & $\begin{array}{l}\text { - Deliberately, denying the victim of } \\
\text { her rights and dues }\end{array}$ & 230 & 32.9 \\
\hline
\end{tabular}

Source: prepared by the researcher from fieldwork, 2010.

Table 4.

Participants perception on the effects of women violence by fellow women.

\begin{tabular}{cccccc}
\hline Perceptions & Percentage & Observed N & Expected N & X & SD \\
\hline Very Satisfied & 14.1 & 99 & 116.7 & & \\
Satisfied & 23.4 & 164 & 116.7 & & \\
Dissatisfied & 30.9 & 216 & 116.7 & 2.82 & 1.17 \\
Very dissatisfied & 26.9 & 188 & 116.7 & & \\
Undecided & 4.7 & 33 & 116.7 & & \\
TOTAL & 100 & 700 & 700 & & \\
\hline
\end{tabular}

Note: $\mathrm{X}^{2}=$ value $298.66 ; \mathrm{df}=5 ; p \leq 0.000$; Source: as analysed from the tables of the field work, 2010. 


\section{A. O. UZUEGBUNAM}

Table 5.

Participants' responses by best considered strategy "Self Searching Management (SSM)" by sex. Summary of best considered strategy "Self Searching Management" (SSM) by sex.

\begin{tabular}{ccccccc}
\hline Gender & SA 5 & A 4 & SD 3 & D 2 & UND 1 & TOTAL \\
\hline Male & 173 & 136 & 0 & 0 & 51 & 360 \\
Female & 104 & 192 & 2 & 1 & 41 & 340 \\
Total & 277 & 328 & 2 & 1 & 92 & 700 \\
\hline
\end{tabular}

Source: as analyzed in Tables 1-4

Table 6.

Summary table of regression analysis showing SSM as the dependent variable.

\begin{tabular}{cccccccccc}
\hline $\begin{array}{c}\text { Independent } \\
\text { Variable }\end{array}$ & Multiple R & \multirow{2}{*}{$\mathrm{R}^{2}$} & Simple R & SE “U” & B Coefficient & SES & Beta & F & Significance \\
\hline Sex & 0.013 & 0.00018 & 0.00125 & 1.14327 & 0.15507 & 0.06429 & 0.0909 & 5.818 & 0.0161 \\
(Constant) & & & & & 0.787332 & 0.09883 & & 63.4660 & 0.0000 \\
\hline
\end{tabular}

Note: dependent variable: Self Searching Management (SSM); Significance level = 0.05 (constant “0”) 0.787332; Source: as analyzed from Table 5.

when the effects of gender are held constant or controlled. SSM evaluation will result in 0.787332 . But since the variable sexmale and female were measured in different units it is the Beta value that shows the relationship of the sex to the perception on SSM. The Beta value indicates 0.0909 and the F value is 5.818 with the significance $F$ as 0.0161 . Therefore, the significance $F$ is less than 0.05 .

\section{Decision}

Since significance $F=0.0161$ is less than $\alpha=0.05$, we reject Ho, and conclude that the relationship between sex and SSM perceptions is not inverse but direct. There is therefore a significant difference between the perceptions of SSM and gender of the respondents.

\section{Discussion}

The main aim of this paper was to determine whether the prevalence of women violence by fellow women is a factor to the persistence of domestic violence against women in Nigerian society and to proffer the best considered strategy towards the reduction of violence against women.

Thus, the prevalence of violence against women by fellow women was confirmed. The study revealed that most common perpetrators are the daughters of same family or clan, co-wives of same family or clan, women in politics, women in same occupation, women in zones of same religious activities. The worst offenders being daughters of same family or clan (Umuada) with the highest score of 297, (42.4\%). Despite the fact that the respondents were from different culture in geopolitical zones of Nigeria, the story was the same problem.

Women most frequently at risk of women violence by fellow women include, the widows, the women political aspirants, the women poor, the women employees, the women great achievers, the childless women and the illiterate women. The childless women and the widows topped the list with $340,(48.6 \%)$ and $318,(45.4 \%)$ respectively. This supports the assertion that it is a curse to be childless or widowed in Nigeria society.

Forms of violence against women by fellow women were indicated as two main categories namely widowhood rituals e.g. drinking of water used in bathing the dead husband and the other category, emotional and psychological violence namely; women and children trafficking, humiliating the victim publicly and privately, controlling what the victim can and cannot do, withholding information from the victim, deliberately denying the victim of her rights and dues, chasing her out of her husband's house, making the victim feel embarrassed and rejected and isolating the victim from her family and friends. The widowhood rituals was regarded as the most common tragedy since it scored the highest marks of $310,(44.3 \%)$ followed by chasing her out of her husband's house with the score of 249 , $(35.6 \%)$ in the ranking order. From these two stem all the other ills against women and children.

The respondent's opinions as to their feeling about the violence against women by fellow women in Nigerian society. Tested through the test of mean, standard deviation and $\mathrm{X}^{2}$ chi-square statistics. The results confirmed that the situation is a human right violation and as such should be challenged. Tested whether a strategy suggested by the research, SSM could help in reducing violence against women, the respondents affirmed that it is worth trying because of its relevance to the solution of human problems as proved by the score $216,(30.0 \%)$ dissatisfied with the violence situation against 99, (14.1\%) satisfied with the situation. Again, tested whether gender affects the participants opinions through the test of regression analysis, the test revealed that there is no significant difference in the opinions of males and females but that the relationship is direct.

\section{Conclusion/Recommendations}

The prevalence of women violence by women themselves is high and has been considered as an important factor in the persistence of violence against women. If the owners of land desecrate the land they live in, they would not blame anybody for the land's extinction. Any house divided among itself can never stand. Thus, if women continue to be their own problem, then the solution of their problems must surely persist overtime. This hinders development which should not be blamed on any factor outside themselves. This is the point of departure from much documented violence against women by other perpetrators. This prompted our best considered strategy for reduction 


\section{A. O. UZUEGBUNAM}

of violence against women as starting from ourselves to address the problem. We are proved to be perpetrators of these infringements on our women folk human rights and privileges. The strategy is "Self Searching management" (SSM). This was also confirmed by the respondents.

Other recommended strategies include; enhancing women education, effective application of the rule of law, encouraging women empowerment, attending to our religious duties and practices, encouraging women in politics, empowerment of gender equality in society, addressing negative traditional and cultural practices and embarking on public enlightenment.

\section{REFERENCES}

Arinze-Umobi, C. (2008). Domestic violence against women in Nigeria: A legal anatomy. Onitsha: Folmech Printing and Pub. Coy Ltd.

Bambale, A. (2004). Sexual harassment in Nigeria's Universities: Causes and Solutions. Nigerian Social Scientist, 7, 24-26.

CDNR (2001). Annual right on the human rights situation in Nigeria. Lagos: Committee for the Defence of Human Rights.
Dugger, C. W. (2007). Progress on citing domestic violence. New York: UN Publications. http://www.query.nytimes.com/

Dukor, M. (2010). How not to empower women, in dukor. Philosophy and politics: Discourse on values, politics and power Africa. Lagos: Malthousse Press Ltd.

Dukor, M. (2010). Feminism in theistic humanism in African philosophy in the global village: Theistic pan psychic axeology and Science. Verlage: Lap Lambert Academic Publishing Gamb Co.

Ezumah, N. (2004). Understanding sexual harassment institutions of higher learning in Nigeria. Nigerian Social Scientist, 7, 19-22.

Hemmasi, M., Graf, L. A., \& Russ, G. S. (1994). Gender-related jokes in the workplaces: Sexual humour or sexual harassment? Journal of Applied Social Psychology, 24, 1114-1128. doi:10.1111/j.1559-1816.1994.tb02376.x

Mallika (2007). Building human rights through popular culture. http://www.breakthrough.ev

UN (1993). Human rights publication; connation for elimination of all forms of domestic violence against women (CEDAW).

US, VWO (2004). Violence against women office. New York.

Uzuegbunam, A. O. (2009). Domestic violence in Nigeria, In M. Ikejiani-Clark (ed.), Peace studies and conflict resolution in Nigeria: A Reader. Ibadan: Spectrum Books Ltd. 